\title{
ITIKAD BAIK DALAM PROSES MEDIASI PERKARA PERDATA DI PENGADILAN
}

\author{
Ajrina Yuka Ardhira dan Ghansham Anand \\ ghansam@fh.unair.ac.id \\ Universitas Airlangga
}

\begin{abstract}
Mediation is a duty which must be taken by the parties wishing to settle its dispute in the Court as specified in the Civil Procedure Code and in accordance with Article 130 HIR and 154 RGB. To improve the regulation of mediation in the Court, the Supreme Court shall issue its Regulation, namely the Supreme Court Regulation No. 1 of 2016 on Mediation Procedures in the Court. Where the regulations on mediation as stipulated in the Supreme Court Regulation No. 1 of 2016 use good faith in its formal conditions. And with such a condition the Supreme Court expects the success rate of mediation in the first level to increase so as to reduce the number of cases accumulated at the Supreme Court. Good faith as a duty to the parties in the Supreme Court Regulation Number 1 Year 2016 is made clear in Article 7 paragraph (1), where there are legal consequences for parties that are considered not having good intentions by doing things listed in Article 7 paragraph (2), namely Article 22 for the plaintiff and Article 23 for the defendant.
\end{abstract}

Keywords: Good Faith; Mediation; Supreme Court Regulation No. 1 of 2016 on Court Mediation Procedures.

\begin{abstract}
Abstrak
Mediasi merupakan kewajiban yang harus ditempuh oleh para pihak yang ingin menyelesaikan sengketanya di Pengadilann sebagaimana yang ditentukan dalam Hukum Acara Perdata dan sesuai pula dengan Pasal 130 HIR dan 154 RGB. Untuk menyempurnakan pengaturan mengenai mediasi di Pengadilan maka Mahkamah Agung mengeluarkan Peraturannya, yakni Peraturan Mahkamah Agung Nomor 1 Tahun 2016 tentang Prosedur Mediasi di Pengadilan. Dimana peraturan mengenai mediasi sebagaimana yang tertera pada Peraturan Mahkmah Agung Nomor 1 Tahun 2016 menggunakan itikad baik dalam syarat formalnya. Dan dengan adanya syarat tersebut Mahkamah Agung mengharapkan tingkat keberhasilan mediasi di tingkat pertama dapat meningkat sehingga mengurangi jumlah penumpukan perkara ditingkat mahkamah agung. Itikad baik sebagai kewajiban bagi para pihak dalam Peraturan Mahkamah Agung Nomor 1 Tahun 2016 dijelakan pada Pasal 7 ayat 1, dimana ada akibat hukum bagi para pihak yang dianggap tidak beritikad baik dengan melakukan hal-hal yang tertera pada Pasal 7 ayat 2, yakni Pasal 22 untuk penggugat dan Pasal 23 untuk tergugat.
\end{abstract}

Kata Kunci: Itikad Baik; Mediasi; Peraturan Mahkamah Agung Nomor 1 Tahun 2016 tentang Prosedur Mediasi di Pengadilan.

\section{Pendahuluan}

Indonesia merupakan negara hukum yang dimana penyelesaian masalah di peradilan dianggap sebagai pelaksana kekuasaan kehakiman yang diatur dalam Undang-Undang Dasar Negara Republik Indonesia 1945 (selanjutnya disebut UUD NRI 1945) sebagai akhir untuk mencari keadilan. Ketentuan-ketentuan mengenai penyelesaian permasalahan di peradilan pun telah diatur dalam Burgelijk Wetboek 
(selanjutnya disebut BW) yang bertujuan untuk menyelesaikan sengketa yang timbul di masyarakat. Tata cara di peradilan pun tidak ketinggalan diatur dalam Hukum Acara Perdata sebagai syarat materiil dapat berlangsungnya proses peradilan.

Hukum acara mengatur bagaimana cara dan siapa yang berwenang menegakan hukum materiil dalam hal apabila terjadi pelanggaran terhadap hukum materiil. Hukum acara perdata secara umum yaitu peraturan hukum yang mengatur proses penyelesaian perkara perdata melalui hakim (di pengadilan) sejak diajukan gugatan, dilaksanakanya gugatan, sampai pelaksanaan putusan hakim. Menurut Wirjono Prodjodikoro, hukum acara perdata ialah rangkaian peraturan yang memuat cara bagaimana orang harus bertindak terhadap dan dimuka pengadilan dan cara bagaimana pengadilan itu harus bertindak satu sama lain untuk melaksanakan berjalanya peraturan hukum perdata. Hukum acara perdata juga disebut hukum perdata formil, yaitu semua kaidah hukum yang menentukan dan mengatur cara bagaimana melaksanakan hak-hak dan kewajiban-kewajiban perdata sebagaimana yang diatur dalam hukum perdata materiil. ${ }^{1}$

Hukum acara perdata menurut Sudikno Mertokusumo adalah peraturan hukum yang mengatur bagaimana caranya menjamin ditaatinya hukum perdata materiil dengan perantara hakim. ${ }^{2}$ Hukum acara perdata adalah peraturan hukum yang menentukan bagaimana caranya menjamin pelaksanaan hukum perdata materiil. Hukum acara perdata yang mengatur bagaimana caranya mengajukan tuntutan hak, memeriksa serta memutuskan dan pelaksanaan dari pada putusanya. Tuntutan hak dalam hal ini tidak lain adalah tindakan yang bertujuan memperolah perlindungan hukum yang diberikan oleh pengadilan untuk mencegah "eigenrichting" atau tindakan menghakimi sendiri. ${ }^{3}$

Apabila dalam hubungan hukum dalam masyarakat, ada yang melakukan pelanggaran terhadap norma atau kaedah hukum perdata sebagaimaana ditentukan

\footnotetext{
${ }^{1}$ Retnowulan Sutantio dan Iskandar Oeripkartawinata, Hukum Acara Perdata dalam Teori dan Praktek, Cetakan ke sebelas, (Mandar Maju, Bandung), 2009, [1-2].

${ }^{2}$ Sudikno Mertokusumo, Hukum Acara Perdata Indonesia, Cetakan ke lima, (Universitas Atma Jaya, Yogyakarta), 2010, [2-3].

${ }^{3}$ ibid
} 
dalam hukum materiill, misalnya pelanggaran hubungan kontraktual dimana penjual tidak menyerahkan barang yang telah dibayarkan harganya, yang tentunya mengakibatkan kerugian kepada pihak pembeli. Maka untuk memulihkan kerugian yang diderita pembeli tersebut, maka hukum materiil yang telah dilanggar harus dipertahankan atau ditegakkan dengan menggunakan sarana hukum acara perdata. Jadi pembeli yang haknya dirugikan karena pelanggaran terhadap kewajiban pembeli tersebut, tidak boleh memulihkan hak perdatanya itu dengan menghakimi sendiri, melainkan harus melalui ketentuan yang diatur dalam hukum acara perdata.

Hukum Acara Perdata pun sangat menghendaki bahkan mengaharuskan mediasi sebelum persidangan dilanjutkan. Sesuai dengan Pasal 130 Herzien Inlandsch Reglement (selanjutnya disebut HIR) maupun Pasal 154 Rechtreglement Voor de Buitengeswesten (selanjutnya disebut RBG). Diharapkan mediasi diawal persidangan dapat berhasil dan mengurangi perkara yang masuk ke Mahkamah Agung dikarenakan menurut data "Ketua MA menjelaskan bahwa beban penanganan perkara tahun 2016 (sampai tanggal 27 Desember 2016, red) sebanyak 18.514 perkara". ${ }^{4}$ Sedangkan pada tahun 2017 "Sepanjang semester pertama tahun 2017 (Januari-Juni), Mahkamah Agung menerima 8. 397 perkara. Menurut Panitera MA, dalam setiap bulannya MA menerima rata-rata 1400 perkara dan memutus rata-rata 1.265 perkara". ${ }^{5}$

Pengaturan mengenai mediasi tidak hanya pada Pasal 130 HIR dan Pasal 154 RGB. Mahkamah Agung (selanjutnya disebut MA) menerbitkan Peraturan Mahkamah Agung Nomor 1 Tahun 2016 (Selanjutnya disebut PERMA No. 1/2016) tentang Prosedur Mediasi di Pengadilan yang dimana ada beberapa perubahan dari PERMA sebelumnya. Perubahan yang paling mendasar adalah seperti berikut: Pertama, batas waktu mediasi menjadi lebih singkat yakni dalam waktu 30 hari

\footnotetext{
${ }^{4}$ Asep Nursobah, 'Penanganan Perkara MA Tahun 2016 : Panen Prestasi' $<$ http://kepaniteraan. mahkamahagung.go.id/index.php/kegiatan/1407-penanganan-perkara-mahkamah-agung-tahun2016-panen-prestasi $>$ accessed 16 September 2017.

${ }^{5}$ Asep Nursobah, 'Semester Pertama 2017, MA Menerima 8379 Perkara'<http://kepaniteraan. mahkamahagung.go.id/index.php/kegiatan/1444-semester-pertama-2017-ma-menerima-8-397perkara $>$ accessed 16 September 2017.
} 
terhitung sejak penetapan perintah melakukan mediasi. Kedua, adanya kewajiban bagi para pihak (inpersoon) untuk menghadiri secara langsung pertemuan mediasi dengan atau tanpa didampingi oleh kuasa hukum, kecuali ada alasan sah seperti kondisi kesehatan yang tidak memungkinkan hadir dalam pertemuan mediasi berdasarkan surat keterangan dokter; di bawah pengampuan; mempunyai tempat tinggal, kediaman atau kedudukan di luar negeri; atau menjalankan tugas negara, tuntutan profesi atau pekerjaan yang tidak dapat ditinggalkan. ${ }^{6}$

Ketiga, hal yang paling baru adalah adanya aturan tentang Itikad Baik dalam proses mediasi dan akibat hukum para pihak yang tidak beriktikad baik dalam proses mediasi. Pasal 7 menyatakan: 1. Para Pihak dan/atau kuasa hukumnya wajib menempuh Mediasi dengan iktikad baik; 2. Salah satu pihak atau Para Pihak dan/ atau kuasa hukumnya dapat dinyatakan tidak beriktikad baik oleh Mediator dalam hal yang bersangkutan:

a. tidak hadir setelah dipanggil secara patut 2 (dua) kali berturut-turut dalam pertemuan Mediasi tanpa alasan sah;

b. menghadiri pertemuan Mediasi pertama, tetapi tidak pernah hadir pada pertemuan berikutnya meskipun telah dipanggil secara patut 2 (dua) kali berturut-turut tanpa alasan sah;

c. ketidakhadiran berulang-ulang yang mengganggu jadwal pertemuan Mediasi tanpa alasan sah;

d. menghadiri pertemuan Mediasi, tetapi tidak mengajukan dan/atau tidak menanggapi Resume Perkara pihak lain; dan/atau

e. tidak menandatangani konsep Kesepakatan Perdamaian yang telah disepakati tanpa alasan sah.

Dari pemaparan diatas, timbullah pertanyaan apakah itikad baik dalam PERMA No. 1/2016 tersebut berpengaruh pada proses dan keberhasilan mediasi, hingga pengaruhnya pada putusan hakim apabila mediasi gagal serta menetapkan salah satu pihak tidak beritikad baik dan dilanjutkan ke proses persidangan selanjutnya. Mengingat dalam hukum perdata sendiri itikad baik merupakan hal yang paling utama bagi hakim untuk menentukan keputusan. Sehingga dengan ini penulis tergerak untuk menelitinya.

${ }^{6}$ YOZ, 'Ini Point Penting Yang Diatur Dalam PERMA no.1 Tahun 2016'<http://www. hukumonline.com/berita/baca/lt56bb2d4541 fd5/ini-poin-penting-yang-diatur-dalam-perma-no1tahun-2016> accessed 2 September 2017. 


\section{Itikad Baik dalam Proses Mediasi}

\section{Mediasi Sebagai Kewajiban Dalam Perkara Perdata di Pengadilan}

MA pun sebagai pelaku kekuasaan kehakiman tertinggi di Indonesia melihat pentingnya mediasi terintegerasi di pengadilan. Selain itu, dengan adanya mediasi perkara yang masuk tidak akan menumpuk banyak, sehingga proses di peradilan akan lebih efektif dan selaras dengan asas sederhana, cepat, dan biaya ringan. Oleh karena hal tersebut Hukum Acara Perdata mewajibkan adanya proses mediasi sebelum persidangan dilanjutkan atau sebelum pembacaan gugatan. Kewajiban mediasi dalam proses Hukum Acara Perdata tersebut sesuai dengan Pasal 130 HIR dan Pasal 154 RBG. Pasal 130 HIR berbunyi:

"Ayat 1: jika pada hari yang ditentukanitu kedua belah pihak dating, maka pengadilan negri dengan pertolongan ketua pengadilan mencoba akan memperdamaikan mereka. ${ }^{7}$

Ayat 2: jika perdamaian yang demikian itu dapat dicapai, maka pada waktu bersidang, diperbuat sebuah surat (akta) tentang itu, dalam makna kedua belah pihak dihukum akan menaati perjanjiang yang diperbuat itu, surat mana akan berkekuatan dan akan dijalankan sebagai putusan yang biasa ${ }^{8}$

Ayat 3: putusn yang sedemikian tidak diijinkan banding.

Ayat 4: jika pada waktu mencoba memperdamaikan kedua belah pihak itu perlu dipakai seorang juru bahasa, maka dalam hal itu hendaklah dituruiti peraturan pasal berikut".

Tetapi Pasal 130 HIR masih terdapat kekosongan hukum, yakni tata cara mediasi belum diatur, sehingga MA mengeluarkan peraturan-peraturan selanjutnya yakni untuk mengoptimalkan penggunaan pasal tersebut hingga prosesnya berjalan dengan baik. Dengan dikeluarkannya peraturan-peraturan selanjutnya hingga yang terakhir ialah PERMA No. 1/2016 tentang prosedur mediasi di Pengadilan, semakin memperkuat bahwa mediasi merupakan hal yang mutlak dilakukan dalam proses peradilan.

\section{Pengecualian Terkait Kewajiban Dalam Menempuh Mediasi}

Mediasi adalah wajib dilakukan oleh para pihak yang bersengketa sesuai dengan proses Hukum Acara Perdata yang pada prinsipnya upaya hakim untuk mendamaikan

\footnotetext{
${ }^{7}$ R. Soesilo, RIB/HIR Dengan Penjelasan, (Politeia).[88].

${ }^{8}$ ibid. [89].
} 
bersifat imperatif ${ }^{9}$ atau harus disampaikan kepada para pihak untuk melakukan proses mediasi. Tetapi kewajiban menempuh mediasi ternyata dapat disimpangi, dan tertuang dalam PERMA No. 1/2016 dijelaskan pada pasal 4 ayat 2, yakni :

"Sengketa yang dikecualikan dari kewajiban penyelesaian melalui Mediasi sebagaimana dimaksud apda ayat 1 meliputi antara lain :

a. sengketa yang pemeriksaannya di persidangan ditentukan tenggang waktu penyelesaiannya meliputi antar lain :

1. sengketa yang diselesaikan melalui prosedur Pengadilan Niaga;

2. sengketa yang diselesaikan melalui prosedur Pengadilan Hubungan Industrial;

3. keberatan atas putusan Komisi Pengawas Persaingan Usaha;

4. keberatan atas putusan Badan Penyelesaian Sengketa Konsumn;

5. permohonan pembatalan putusan arbitrase;

6. keberatan atas putusan Komisi Informasi;

7. penyelesaian perselisihan partai politik;

8. sengketa yang diselesaikan melalui tata cara gugatan sederhana; dan

9. sengketa lain yang pemeriksaanya di persidangan ditentukan tenggang waktu penyelesaiannya dalam ketentuan peraturan perundangundangan;

b. sengketa yang pemeriksaannya dilakukan tanpa hadirnya penggugat atau terugat yang telah dipanggil secara patut;

c. gugatan balik (rekonvensi) dan masuknya pihak ketiga dalam suatu perkara(intervensi)

d. sengketa mengenai pencegahan, penolakan, pembatalan dan pengesahan perkawinan;

e. sengketa yang diajukan ke Pengadilan setelah diupayakan penyelesaian di luar Pengadilan melalui Mediasi dengan bantuan Mediator bersetifikat yang terdaftar di pengadilan setempattetapi dinyatakan tidak berhasil berdasarkan pernyataan yang ditandatangani oleh Para Pihak dan Mediator bersertifikat."

Pengecualian kewajiban menempuh mediasi seperti yang telah dijelaskan pada Pasal 4 ayat 2 tersebut menjelaskan bahwa kewajiaban tersebut ternyata dapat disampingkan. Penyimpangan tersebut bukan terjadi karena tidak adanya alasan. Menurut Mohammad saleh ${ }^{10}$ sebagai salah satu tim perancang PERMA No. 1/2016 tentang prosedur mediasi menjelaskan beberapa hal mengenai mengapa ada pengecualian kewajiban menempuh mediasi. Sebagai contoh yakni pada

${ }^{9}$ M.Yahya Harahap, Hukum Acara Perdata (Tentang Gugatan, Persidangan, Penyitaan, Pembuktian, Dan Putusan Pengadilan) Edisi Kedua (Sinar Grafika ed, 2017).[239].

${ }^{10}$ Mohammad Saleh, 'Wawancara Pada Tanggal 17 Oktober' (2017). 
Pasal 4 ayat 2 huruf a, mengenai mediasi dalam Pengadilan Hubungan Industrial (selanjutnya disebut PHI). Dalam PHI sendiri sebelum perkara tersebut masuk kerana pengadilan, sudah diadakan mediasi terlebih dahulu oleh lembaga ketenaga kerjaan yang menaungi. Sedangkan mengenai kepailitan, dikecualikan dari adanya mediasi karena telah jelas melalui pembuktian sederhana yang menjelaskan kerugian yang dialami oleh salah satu pihak, sehingga jelas pihak lainnya harus bertanggung gugat oleh hal tersebut.

Pasal 4 ayat 2 huruf a, c, dan e yang sebenarnya dikecualikan dari prosedur wajib mediasi. Tetapi apabila para pihak yang bersengketa berkeinginan untuk melalui prosedur mediasi sebelum sengketa diperiksa sebgaimana sengketa yang tidak dikecualikan, maka proses mediasi bisa dilakukan terhadap perkara terseut. Tetapi sifat dan mediasinya adalah sukarela atau volunteer yang dilakukan pada tahap pemeriksaan perkara dan tingkat upaya hukum sebagaimana diatur dalam Pasal 4 ayat 4 PERMA No. $1 / 2016 .^{11}$

\section{Itikad Baik Sebagai Syarat Formal Mediasi}

Black's Law Dictianory menjelaskan bahwa itikad baik (good faith) adalah: "A state of mind consisting in (1) honesty in belief or purpose, (2) faithfulness to one's duty or obligation, (3) observance of reasonable commercial standarts of fair dealing in a given trade or business, or (4) absence of intent to defraud or to seek unconscionable advantage". ${ }^{12}$

Itikad baik pun tercantum dalam BW Pasal 1338 ayat 3 BW yang menyatakan bahwa “...perjanjian harus dilaksanakan dengan itikad baik”. Dan menurut Wirjono Prodjodikoro dalam melaksanakan perbuatan apapun harus berdasarkan kejujuran dan berjalan dalam hati sanubari seorang manusia. Jadi apapun yang dilakukan manusia sebagai anggota masyarakat harus jauh dari sifat merugikan orang lain dan

\footnotetext{
${ }^{11}$ Maskur Hidayat, Strategi \& Taktik Mediasi Berasarkan Perma No. 1 Tahun 2016 Tentang Prosedur Mediasi Di Pengadilan (Kencana Prenada Media Group 2016).[74].

12 Bryan A. Garner, Black's Law Dictianory, Tenth Edition, (West Publishing Company, USA).[808].
} 
menguntungkan diri sendiri. ${ }^{13}$ Serta itikad baik sebagaimana yang dimaksud diatas bermakna bahwa para pihak wajib untuk saling berbuat baik. ${ }^{14}$

Itikad baik dalam mediasi dituangkan sebagai syarat formal dalam Pasal 7 ayat 1 PERMA No. 1/2016 yang berbunyi "Para Pihak dan/atau kuasa hukumnya wajib menempuh mediasi dengan itikad baik". Mengenai itikad baik ini memang hal yang baru karena tidak tertuang dalam peraturan sebelumnya. Mengacu pada proses mediasi yang berlangsung selama ini, para pihak tidak beritikad baik yang mengakibatkan mediasi selalu saja gagal. Sehingga itikad baik pun dijadikan point penting didalam proses mediasi sesuai dengan PERMA No.1/2016 ini.

\section{Daya Mengikat Pejanjian Perdamaian}

Akta perdamaian yang telah didasarkan atas putusan majelis hakim di pengadilan sudah mempunyai kekuatan eksekutorial. Dimana apabila salah satu pihak tidak mentaati atau tidak melaksanakan isi yang tertuang dalam akta perdamaian tersebut secara sukarela maka dapat dimintai eksekusi kepada pengadilan negeri, sehingga ketua pengadilan negeri memerintahkan pelaksanaan eksekusi. Putusan tersebut tidak dapat upaya banding, kasasi, maupun peninjauan kembali, Sesuai juga dengan Pasal 130 ayat 3 HIR yang berbunyi "Putusan yang sedemikian tidak diizinkan banding”.

Putusan yang dapat dieksekusi adalah putusan Condemnatoir yaitu putusan yang amar atau diktumnya bersifat menghukum atau memenuhi klausula kesepakatan perdamaian sesuai yang disepakati para pihak. Oleh sebab karena memiliki kekuatan mengikat, kekuatan pembuktian dan kekuatan eksekutorial maka akta perdamaian memiliki kepastian hukum layaknya putusan yang berkekuatan hukum tetap.

Akta perdamaian atau putusan perdamaian juga tidak dapat dibatalkan oleh salah satu pihak yang merasa dirugikan dari adanya akta perdamaian tersebut. Dikarenakan pada prinsipnya akta perdamian yang telah diputus oleh hakim tersebut

\footnotetext{
${ }^{13}$ Wirjono Prodjodikoro, Azas-Azas Hukum Perjanjian (Mandar Maju 2000).[102].

14 J.H. Niewenhuis, 'Pokok-Pokok Hukum Perikatan', (Terjemahan Djasadin Saragih) (1985).[43].
} 
berasal dari kesepakatan-kesepakatan kedua belah pihak yang bersengketa secara bersama-sama. Sehingga akta perdamaian tersebut mengikat kedua belah pihak yang telah sepakat dalam mempuat perjanjian perdamaian yang lalu di putus oleh hakim menjadi akta perdamaian. Atau dengan kata lain tidak ada upaya hukum apapun yang dapat dilakukan oleh kedua belah pihak dikemudian harinya.

\section{Akibat Hukum dari Pelanggaran Itikad Baik dalam Proses Mediasi di Pengadilan.}

\section{Hambatan-Hambatan dalam Upaya Mediasi di Pengadilan}

Hambatan-hambatan juga timbul dari pelaksana mediasi sendiri yang pertama, kurangnya dukungan dari MA. Salah satu contoh kurangnya MA dalam menjadikan mediasi itu sendiri sebagai program prioritas, hal tersebut terlihat dari belum dikeluarkannya kebijakan mengenai jenjang karir dan insentif bagi hakim yang menjalankan fungsi mediator. Padahal hal tersebut dapat memotivasi hakim itu sendiri untuk dapat menyelesaikan sengketa dengan mediasi. ${ }^{15}$ Yang kedua, rendahnya motivasi mediator dari hakim. Banyak hakim di pengadilan tingkat pertama sebagai ujung tombak pelaksanaan mediasi tidak sepenuh hati menyelesaikan sengketa yang dihadapinya secara damai. Hal tersebut dilakukan karena mereka merasa hanya mendapat sedikit manfaat atau bahkan tidak sama sekali. ${ }^{16}$ Dan yang ketiga, dari sisi kuasa hukum. Dalam hal melakukan mediasi, banyak kuasa hukum yang merasa kurang yakin terhadap efektivitas dari mediasi, terutama pada segi kekuatan eksekusi kesepakatan yang dicapai nantinya. Selain itu kuasa hukum terbiasa dengan pola pikir litigasi, apalagi jika posisinya kuat, kemengangan dapat dicapai melalui litigasi walaupun mungkin akan memakan waktu yang lama tetapi akan lebih pasti apabila dijatuhkan dengan putusan akhir. Selain dari segi pola pikirnya, kuasa hukum akan beranggapan penyelesaian sengketa dengan mediasi akan mengurangi pendapatan mereka. Karena pada umumnya yang bersengketa dan menggunakan jasa kuasa hukum

${ }^{15}$ Fatahilah A. Syukur, Mediasi Yudisial Di Indonesia: Peluang Dan Tantangan Dalam Memajukan Sistem Peradilan (Mandar Maju 2012).[63].

16 ibid. 
untuk membelanya akan membayar jasa kuasa hukum tersebut sesuai waktu penyelesaian sengketa atau setelah selesai menangani sengketa tersebut.

\section{Akibat Hukum Atas Pelanggaran Itikad Baik Dalam Mediasi}

Konsep itikad baik dalam PERMA No.1/2016 mulai dikembangkan dan memiliki akibat bagi pelanggarnya. Klasifikasi itikad baik pun dijelaskan dalam Pasal 7 ayat 2 yang menyatakan bahwa :

"Salah satu pihak dan/atau kuasa hukumnya dapat dinyatakan tidak beritikad baik oleh mediator dalam hal yang bersangkutan:

a. Tidak hadir setelah dipanggil secara patut 2 (dua) kali berturut - turut dalam pertemuan mediasi tanpa alasan sah;

b. Mengadiri pertemuan mediasi pertama, tetapi tidak pernah hadir pada pertemuan berikutnya meskipun telah dipanggil secara patut 2 (dua) kali berturut-turut tanpa alasan yang sah;

c. Ketidakhadiran berulang - ulang yang mengganggu jadwal pertemuan mediasi tanpa alasan yang sah;

d. Menghadiri pertemuan mediasi, tetapi tidak mengajukan dan/atau tidak menanggapi resume perkara pihak lain, dan/atau;

e. Tidak menandatangani konsep kesepakatan perdamaian yang telah disepakati tanpa alasan yang sah".

Apabila penggugat dinyatakan tidak bertikad baik dalam proses mediasi sebagaimana yang dimaksud dalam Pasal 7 ayat 2 diatas, maka gugatan dinyatakan tidak dapat diterima oleh haikim pemeriksa perkara (Pasal 22 ayat 1 PERMA No. 1/2016). Penggugat yang tidak bertikad tidak biak juga dikenakan kewajiban membayar biaya mediasi (Pasal 22 ayat 2 PERMA No. 1/2016). Sebaliknya apabila tergugat dinyatakan tidak beritikad baik, maka terhadapnya dikenakan kewajiban untuk membayar biaya mediasi (Pasal 23 ayat 1 PERMA No. 1/2016). Penjelasan mengenai akibat tidak beritikad baik dalam PERMA No. 1/2016 yang dijelaskan pada Pasal 22 dan Pasal 23:

"Pasal 22:

1. Apabila penggugat dinyatakan tidak bertikad baik dalam proses mediasi sebagaimana yang dimaksud dalam Pasal 7 ayat 2, gugatan dinyatakan tidak dapat diterima oleh Hakim Pemeriksa Perkara;

2. Penggugat yang dinyatakan tidak beritikad baik sebagaimana yang dimaksud pada ayat 1 dikenai pula kewajiban pembayaran biaya mediasi;

3. Mediator menyampaikan laporan penggugat tidak beritikad baik kepada 
Hakim Pemeriksa Perkara disertai rekomendasi pengenaan biaya mediasi dan perhitungan besarnya dalam laporan ketidakberhsilan atau tidak dapat dilaksanakannya mediasi;

4. Berdasarkan laporan mediator sebagaimana dimaksud pada ayat 3, Hakim Pemeriksa Perkara mengeluarkan putusan yang merupakan putusan akhir yang menyatakan gugatan tidak dapat diterima disertai penghukuman pembayaran biaya mediasi dan biaya perkara;

5. Biaya mediasi sebagai penghukuman kepada penggugat dapat diambil dari panjar biaya perkara atau pembayaran tersendiri oleh penggugat dan diserahkan pada tergugat melalui kepaniteraan Pengadilan.

Pasal 23:

1. Tergugat yang dinyatakan tidak beritikad baik sebagaimana dimaksud dalam Pasal 7 ayat 2, dikenai kewajiban membayar biaya mediasi;

2. Mediator menyampaikan laporan tergugat tidak beritikad baik kepada Hakim Pemeriksa Perkars disertai rekomendasi pengenaan biaya mediasi dan perhitungan besarnya dan laporan ketidak berhasilan atau tidak dapat dilaksanakannya mediasi;

3. Berdasarkan laporan mediator sebagaimana yang dimaksud pada ayat 2, sebelum melanjutkan pemeriksaan, Hakim Pemeriksa Perkara dalam persidangan yang ditetapkan berikutnya wajib mengeluarkan penetapan yang menyatakan tergugat tidak beritikad baik dan menghukum tergugat untuk membayar biaya mediasi;

4. Biaya mediasi sebagaimana dimaksut pada ayat 3 merupakan bagian dari biaya perkara wajib disebutkan dalam amar putusan akhir;

5. Dalam hal tergugat sebagaimana dimaksud pada ayat 1 dimenangkan dalam putusan, amar putusan menyatakan biaya mediasi dibebankan kepada tergugat, sedangkan biaya perkara tetap dibebankan kepada penggugat;

6. Dalam perkara perceraian di lingkungan Peradilan Agama, tergugat sebagaimana dimaksud pada ayat 1 dihukum membayar biaya mediasi, sedangkan biaya perkara dibebankan kepada penggugat;

7. Pembayaran biaya mediasi oleh tergugat yang akan diserahkan kepada penggugat melalui kepaniteraan pengadilan mengikuti pelaksanaan putusan yang telah berkekuatan hukum tetap;

8. Dalam hal para pihak secara bersama-sama dinyatakan tidak beritikad baik oleh mediator, gugatan dinyatakan tidak diterima oleh Hakim Pemeriksa Perkara tanpa penghukuman biaya mediasi."

\section{Fungsi Mediator Dalam Penyelesaian Sengekta Melalui Mediasi}

Pengertian mediator juga dijelaskan dalam Black's Law Dictionary yang berbunyi : "Neutral person who tries help disputing parties reavh an aggrement", ${ }^{17}$

${ }^{17}$ Bryan A Garner.Op.Cit.[808]. 
yang berarti mediator merupakan seseorang yang netral dalam membantu menyelesaikan sengketa. Dalam menjalankan kewajibannya menjadi mediator harus ada syarat-syarat agar proses mediasi dapat berhasil. Persyaratan menjadi seorang mediator dapat dilihat dari dua sisi, yaitu sisi internal dan sisi eksternal.

Dalam hal tahapan tugas mediator, PERMA No. 1/2016 menjelaskan pada Pasal 14 yakni:

"Dalam menjalankan fungsinya, mediator bertugas:

a. Memperkenalakan diri dan memberi kesempatan kepada para pihak untuk saling memperkenalkan diri;

b. Menjelaskan maksud, tujuan, dan sifat mediasi kepada para pihak;

c. Menjelaskan kedudukan dan peran mediator yang netral dan tidak mengambil keputusan;

d. Membuat aturan pelaksanaan mediasi bersama para pihak;

e. Menjelaskan bahwa mediator dapat mengakan pertemuan dengan satu pihak tanpa kehadiran pihak lainnya (kaukus);

f. Menyusun jadwal mediasi dengan para pihak;

g. Mengisi formulir jadwal mediasi;

h. Memberikan kesempatan kepada para pihak untuk menyampaikan permasalahan dan usulan perdamaian;

i. Menginventarisasi permasalahan dan mengadendakan pembahasan berdasarkan skala prioritas;

j. Memfalitasi dan mendorong para pihak untuk :

1. Menelusuri dan menggali kepentingan para pihak;

2. Mencari berbagai pilihan penyelesaian yang terbaik bagi para pihak; dan

3. Bekerja sama mencapai penyelesaian;

k. Membantu para pihak dalam membuat dan merumuskan kesepakatan perdamaian;

1. Menyampaikan laporan keberhasilan, ketidakberhasilan dan/atau tidak dapat dilaksanakannya mediasi kepada Hakim Pemeriksa Perkara;

m. Menyatakan salah satu atau para pihak tidak beritikad baik dan menyampaikan kepada Hakim Pemeriksa Perkara;

n. Tugas lain dalam menjalankan fungsinya."

Dengan tujuan mengetahui secara jelas inti permasalahan yang dialami para pihak, mediator dapat melakukan kaukus. Kaukus adalah pertemuan antara mediator dengan salah satu pihak tanpa dihadiri oleh pihak lainnya (Pasal 1 ayat 4 PERMA No. 1/2008). Dengan demikian, kaukus merupakan pengecualian dari prinsip umum yang mengharuskan setiap pertemuan harus dihadiri oleh para pihak. Dalam hal kaukus dilakukan tergantung pada pertimbagan mediator apakah hal tersebut perlu 
atau tidak dan harus mempertimbangkan hal tersebut secara sungguh-sungguh, selain itu tidak perlu adanya persetujuan dari para pihak maupun dari pihak lainnya. ${ }^{18}$

Mediator dalam melaksanakan tugasnya juga juga harus mengingat bahwa mediasi bertujuan untuk membantu para pihak mencapai kesepakatan perdamaian. Karena orientasi mediasi sendiri adalah pada hasil berupa para pihak mau menyelesaikan sengketa melalui kesepakatan damai. Tetapi hal itu dilakukan atas kerelaan para pihak, bukan dari paksaan agar berdamai. Karena sepanjang klausul yang disepakati para pihak tidak bertentangan dengan hukum, tidak melanggar hak orang lain serta dapat dilaksanakan maka mediasi pada dasarnya telah terlaksana pada jalur yang benar.

Apabila mediasi yang dilakukan gagal, maka mediator dilarang menjadi saksi dalam proses persidangan perkara yang bersangkutan. Dalam hal ini PERMA menempatkan eks-mediator dalam kedudukan tidak cakap menjadi saksi, khusus dalam sengketa tersebut. Namun terhadap perkara lain, tetap cakap menjadi seorang saksi sepanjang tidak bertentangan dengan ketentuan Pasal 145 HIR dan Pasal 1909 BW. Serta segala apa saja yang diajukan, disampaikan, maupun yang diakui oleh para pihak dalam proses mediasi tidak dapat dijadikan sebagai alat bukti sesuai dengan Pasal 164 HIR dan Pasal 1866 BW.

\section{Kesimpulan}

Berdasarkan penjelasan yang telah diuraikan pada bab-bab sebelumnya baik dari sumber yang diperoleh melalui studi kepustakaan maupun peraturan perundangundangan, maka dapat disimpulkan sebagai berikut :

1. Mediasi merupakan kewajiban yang harus dilakukan oleh para pihak yang ingin menyelesaikan sengketa di pengadilan sesuai dengan prosedur Hukum Acara Perdata. Selain kewajiban tersebut, manfaat mediasi sangatlah banyak dan sangat menguntungkan untuk para pihak. Serta terdapat penekanan mengenai Itikad baik yang harus dilakukan oleh para pihak yang bersengketa dan dijelaskan

${ }^{18}$ M.Yahya Harahap.Op.Cit.[262-263]. 
pada Pasal 7 ayat 2 PERMA No. 1/2016 sebagai syarat formal dalam mediasi agar mediasi itu sendiri tidak lagi dianggap sebagai formalitas saja.

2. sanksi dari pelanggaran itikad baik yang dilejelaskan dalam Pasal 7 ayat 2 PERMA No. 1/2016 tentang Prosedur Mediasi di Pengadilan terdapat pada Pasal 22 dan Pasal 23 PERMA N. 1/2016. Dimana apabila penggugatlah yang dianggap tidak beritikad baik, maka gugatan yang diajukan oleh penggugat dinyatakan tidak dapat diterima dan jatuhlah Putusan NO serta dikenakank pula kewajiban membayar biaya mediasi. sedangkan apabila tergugatlah yang dianggap tidak beritikad baik, maka terhadap tergugat tersebut diberi penghukuman untuk membayar biaya mediasi.

\section{Daftar Bacaan}

\section{Buku}

Bryan A. Garner, Black's Law Dictianory, Tenth Edition, (West Publishing Company, USA).

Fatahilah A. Syukur, Mediasi Yudisial Di Indonesia : Peluang Dan Tantangan Dalam Memajukan Sistem Peradilan (Mandar Maju 2012).

J.H. Niewenhuis, 'Pokok-Pokok Hukum Perikatan', (Terjemahan Djasadin Saragih) (1985).

Maskur Hidayat, Strategi \& Taktik Mediasi Berasarkan Perma No. 1 Tahun 2016 Tentang Prosedur Mediasi Di Pengadilan (Kencana Prenada Media Group 2016).

M.Yahya Harahap, Hukum Acara Perdata (Tentang Gugatan, Persidangan, Penyitaan, Pembuktian, Dan Putusan Pengadilan) Edisi Kedua (Sinar Grafika ed, 2017).

Retnowulan Sutantio dan Iskandar Oeripkartawinata, Hukum Acara Perdata dalam Teori dan Praktek, Cetakan ke sebelas, (Mandar Maju, Bandung), 2009.

R. Soesilo, RIB/HIR Dengan Penjelasan, (Politeia).

Sudikno Mertokusumo, Hukum Acara Perdata Indonesia, Cetakan ke lima, (Universitas Atma Jaya, Yogyakarta), 2010. 
Wirjono Prodjodikoro, Azas-Azas Hukum Perjanjian (Mandar Maju 2000).

\section{Perundang-undangan}

Herzien Inlandsch Reglement (HIR).

Rechtreglement Voor de Buitengeswesten (RBG).

Peraturan Mahkamah Agung Nomor 1 Tahun 2016.

Peraturan Mahkamah Agung Nomor 1 Tahun 2008.

\section{Laman}

Asep Nursobah, 'Penanganan Perkara MA Tahun 2016 : Panen Prestasi' <http:// kepaniteraan.mahkamahagung.go.id/index.php/kegiatan/1407-penangananperkara-mahkamah-agung-tahun-2016-panen-prestasi> accessed 16 September 2017.

Asep Nursobah, 'Semester Pertama 2017, MA Menerima 8379 Perkara' <http:// kepaniteraan.mahkamahagung.go.id/index.php/kegiatan/1444-semesterpertama-2017-ma-menerima-8-397-perkara> accessed 16 September 2017.

YOZ, 'Ini Point Penting Yang Diatur Dalam PERMA no.1 Tahun 2016' <http:// www.hukumonline.com/berita/baca/lt56bb2d4541fd5/ini-poin-pentingyang-diatur-dalam-perma-no1-tahun-2016> accessed 2 September 2017. 